\title{
Application of Nejayote as a Foliar and Edaphic Fertiliser to Native Blue Maize (Zea mays L.) Crops
}

\author{
Victoria Téllez ${ }^{1}$, Jesús F. López² ${ }^{2}$ Agustín Aragón², Teresa Zayas³ \\ ${ }^{1}$ Posgrado en Manejo Sostenible de Agroecosistemas, BUAP, Puebla, México \\ ${ }^{2}$ Centro de Agroecología, BUAP, Puebla, México \\ ${ }^{3}$ Posgrado en Ciencias Ambientales, Instituto de Ciencias, Benemérita Universidad Autónoma de Puebla (BUAP), Puebla, México \\ Email: tzayasp@hotmail.com, teresa.zayas@correo.buap.mx
}

How to cite this paper: Téllez, V., López, J.F., Aragón, A. and Zayas, T. (2016) Application of Nejayote as a Foliar and Edaphic Fertiliser to Native Blue Maize (Zea mays L.) Crops. American Journal of Plant Sciences, 7, 2221-2238.

http://dx.doi.org/10.4236/ajps.2016.715196

Received: October 5, 2016

Accepted: November 7, 2016

Published: November 10, 2016

Copyright $\odot 2016$ by authors and Scientific Research Publishing Inc. This work is licensed under the Creative Commons Attribution International License (CC BY 4.0).

http://creativecommons.org/licenses/by/4.0/

\begin{abstract}
Raw and treated "nejayote" were assessed as foliar and edaphic fertilisers for native blue maize (Zea mays L.) crops in the municipality of Amozoc de Mota, Puebla, Mexico, during the 2015 agricultural cycle. Treated nejayote refers to raw nejayote subjected to a coagulation-flocculation process. Two states of nejayote were established (raw and treated nejayote) with different physicochemical properties. Foliar bio-fertilisers were prepared from raw and treated nejayote and mixed with organic matter $(\mathrm{OM})$ to promote a fermentation process. The foliar treatments used were: BNC5, BNC15, BNC30 (raw nejayote-based bio-fertiliser at 5\%, 15\%, and 30\%), BNCQ5, and NCQ30 (nejayote treated by chemical coagulation at 5\% and 30\%), with BT as a control (traditional bio-fertiliser). The edaphic treatments used were: NC50, NC75, and NC100 (raw nejayote at 50\%, 75\%, 100\%), with AP as a control (drinking water), thus giving rise to 10 treatments in terms of content of raw or treated nejayote. Foliar and edaphic field treatments applied to native blue maize crops were statistically assessed using the following response variables: plant height, stem diameter, number of leaves, and grain yield. The experiment was laid out in a randomised complete block design (RCBD) with five replications of each treatment. The results obtained showed, that foliar or edaphic application at the different stages of development did not produce statistically significant differences, at $\mathrm{P} \leq 0.05$, in terms of response variables. The most significant effects occurred at the early stage of plant development and were mainly reflected in the stem diameter with foliar treatment NCQ30 and in the number of leaves with foliar treatment BNC5. At the final stage of crop development, the highest yield $\left(0.639 \pm 0.121 \mathrm{t} \cdot \mathrm{ha}^{-1}\right)$ was obtained with treatment BNC5, which produced a statistically significant difference (b) in relation to the rest of the foliar and edaphic treatments (Tukey $\mathrm{P} \leq 0.05$ ).
\end{abstract}




\section{Keywords}

Maize Crop, Foliar-Edaphic Fertiliser, Raw Nejayote, Treated Nejayote

\section{Introduction}

The nixtamalisation process is a fundamental stage in the elaboration of the "tortilla", involving the alkaline cooking of maize grains. According to Cortés et al. (2005) [1], nixtamalisation only requires lime and water for the alkaline cooking of maize. Furthermore, the proportion of water and lime and cooking temperature may vary within given intervals: water $120 \%-130 \%$ and lime $0.1 \%-5.0 \%$ (on an original corn mass basis) at $80^{\circ} \mathrm{C}-100^{\circ} \mathrm{C}$ for $0.25-3.0 \mathrm{~h}$ and is the steeped for up to $24 \mathrm{~h}$ between $40^{\circ} \mathrm{C}$ and $100^{\circ} \mathrm{C}[2]$. The residual water that results from the nixtamalisation process is known as "nejayote". Nejayote production is abundant, as a tonne of processed maize requires 3 $\mathrm{m}^{3}$ of water, thus rendering an annual nejayote production of $16-22$ million $\cdot \mathrm{m}^{3}$ [3]. In terms of composition, nejayote is rich in organic matter (OM) $\left(25,000-28,000 \mathrm{mgO}_{2} \cdot \mathrm{L}^{-1}\right)$, nitrogen (200 - $300 \mathrm{ppm})$, phosphorus (160 - $190 \mathrm{ppm}$ ), and metal ions. Such characteristics cause this residual water to have agricultural value [4]. The nutritional status of plants and croplands is improved by fertilisers [5]; for increased crop productivity, quality and nutrient use efficiency, organic sources, bio-fertilisers and micro-nutrients provided through soil application, foliar spray, or seed treatment can be used [6] [7]. Furthermore, the application of fertilisers has become an important biofortification approach to raise mineral content, especially in cereal grains [8]. Aghofack et al. (2010) [9] made a soil and foliar application of calcium- and magnesium-based fertilisers to tomato, producing a reduced incidence and severity of fungal diseases and positive responses in plant health, growth, and yield. Smith et al. (2015) [10] determined that the application of biosolids with urea gave comparable crop yields to ammonium nitrate fertiliser when applied as a top-dressing to forage maize. From this perspective, nejayote may be used in the agricultural sector as compost or as an organic fertiliser. The purpose of this work was to research the influence of raw and treated nejayote as foliar and edaphic fertilisers on the development of native blue maize (Zea mays L.) during the 2015 agricultural cycle, in the region of Amozoc de Mota, Puebla, México. Raw and treated nejayote entail two different states with dissimilar organic and inorganic contents and physicochemical properties. Treated nejayote was obtained from raw nejayote subjected to a coagulation-flocculation process with the Südflock ${ }^{\circledR}$ P-63 coagulant and the Sumex Biofloc $c^{\circledast}$ A-01 flocculent, under specific conditions. This treatment allowed the removal of colloidal particles from the residual water and, therefore, partial removal of the organic content [11] [12] [13]. Blue native maize (Zea mays L.) was the variety selected in this work to analyse the influence of nejayote as an agricultural fertiliser, given its highly nutritious content, its high content of antioxidant compounds, its high fibre level, and its easily digestible carbohydrates. In terms of characterisation, blue maize presents elongated cobs and purple-blue grains. These grain co- 
lours are attributed to the presence of anthocyanins found mainly in the pericarp and the aleurone layer or in both structures [1]. These natural pigments are considered safe for human consumption and are effective food additives [14] [15]. In addition, anthocyanins may prevent damage caused by active oxygen radicals in living systems [14] [16] [17]. However, the cultivation of the blue maize in Mexico is limited, and sowing is only performed on a temporary basis, mainly in the high central valley [18].

\section{Materials and Methods}

\subsection{Sampling and Characterization of Raw Nejayote}

Nejayote (or residual water from the nixtamalisation process) used in this work was collected from a nixtamal grinder in the municipality of Amozoc de Mota, Puebla, Mexico. Nejayote was stored in 20-L plastic containers and kept refrigerated at $4^{\circ} \mathrm{C}$ throughout the experimental work. Raw nejayote and nejayote treated by coagulation-flocculation were characterised following these physicochemical parameters: $\mathrm{pH}$, electric conductivity, Chemical Oxygen Demand (COD), total colour, turbidity, total solids (TS), OM, and content elements (nitrogen, phosphorus, potassium, calcium, magnesium, iron, manganese, copper, and zinc). The $\mathrm{pH}$ level and electric conductivity were determined with a Conductronic PC 16 potentiometer. Furthermore, COD, colour, and turbidity were determined with a Merck 118 photometer. TS and OM were determined with a Thermolyn ${ }^{\circledR}$ Benchtop muffle, and total nitrogen was determined with a Kjeldahl of block SEV ${ }^{\circledR}$ digester. Phosphorus, potassium, calcium, magnesium, iron, manganese, copper, and zinc were determined using an atomic absorption spectrophotometer (Perkin Elmer AANALYST 200).

\subsection{Nejayote Treated by a Coagulation-Flocculation Process}

Treated nejayote was obtained from raw nejayote subjected to a coagulation-flocculation process with the Südflock ${ }^{\oplus}$ P-63 coagulant (alkali-activated aluminosilicate) and the Sumex Biofloc ${ }^{\oplus}$ A-01 flocculent (polyacrylamide, anionic polymer). This process reduced the organic content, colour, and turbidity with respect to raw nejayote. The coagulation-flocculation process applied to raw nejayote was previously studied in terms of $\mathrm{pH}$, coagulant (Südflock $\mathrm{P}^{\circledast}$-63) and flocculent dose (Sumex Biofloc ${ }^{\circledR}$ A-01) in a jar tester SEV ${ }^{\circledR}$ AM-3 with multiple agitators. Both the coagulant and the flocculent were provided by Süd-Chemie de México S.A. de C.V. The statistical analysis of the experimental data on the coagulation-flocculation process obtained with respect to $\mathrm{pH}$, coagulant (Südflock ${ }^{\oplus}$ P-63) and flocculent concentration (Sumex Biofloc ${ }^{\oplus}$ A-01) allowed selecting the conditions of the coagulation-flocculation treatment to reduce the turbidity, colour, and COD with respect to raw nejayote. These conditions were established with the following parameters: $\mathrm{pH}=9 ; 0.20 \times 10^{-3} \mathrm{~g} \cdot \mathrm{L}^{-1}$ flocculent (Sumex Biofloc ${ }^{\bullet} \mathrm{A}-01$ ), and 7.5 to $11.5 \mathrm{~g} \cdot \mathrm{L}^{-1}$ coagulant (Südflock ${ }^{\circledR} \mathrm{P}-63$ ).

\subsection{Preparation of the Bio-Fertilisers from Raw and Treated Nejayote for Foliar Application}

Bio-fertilisers were labelled as follows: BT, for a traditional bio-fertiliser with drinking 
water as a control; BNCQ, for a bio-fertiliser from nejayote treated by a coagulationflocculation process; and BNC, for a bio-fertiliser from raw nejayote. BT is constituted by $19.20 \mathrm{~L}$ of drinking water, $11.00 \mathrm{~kg}$ of manure, $0.28 \mathrm{~kg}$ of ash, $1.10 \mathrm{~kg}$ of molasses, $6.60 \mathrm{~L}$ of milk serum, $0.70 \mathrm{~kg}$ of alfalfa leaves (Medicago sativa), $0.70 \mathrm{~kg}$ of xicalote leaves (Argemone mexicana), $0.11 \mathrm{~kg}$ of yeast, and $0.28 \mathrm{~L}$ of male human urine. The preparation process was as follows: 19.20 L of drinking water (for BT) or raw nejayote (for BNC) or nejayote treated by coagulation (for BNCQ) was added into a container. Then, we incorporated into the water $11.00 \mathrm{~kg}$ of manure, $0.28 \mathrm{~kg}$ of ash, $1.10 \mathrm{~kg}$ of molasses, $6.60 \mathrm{~L}$ of milk serum, $0.70 \mathrm{~kg}$ of alfalfa leaves (Medicago sativa), $0.70 \mathrm{~kg}$ of xicalote leaves (Argemone mexicana), $0.11 \mathrm{~kg}$ of yeast, and $0.28 \mathrm{~L}$ of male human urine. All these ingredients were mixed until a homogeneous product was obtained. Then, bio-fertilisers were placed in 20-L biodigesters and were hermetically sealed. Each biodigester was connected to a bottle containing $0.30 \mathrm{~L}$ of drinking water, to dissolve the $\mathrm{CO}_{2}$ produced by fermentation. The mixture was allowed to ferment for 60 days. During this fermentation process, $0.83 \mathrm{~L}$ of serum and $0.55 \mathrm{~L}$ of molasses were added to each biodigester on four occasions (every $72 \mathrm{~h}$ ). The biodigesters were kept in a cool and dry place throughout the fermentation stage. The total number of bio-fertilisers prepared is shown in Table 1, which also includes the number of treatments, the type of fertiliser (foliar or edaphic), the name of the treatment, the percentage of dilution used, and the corresponding symbol.

\subsection{Preparation of Edaphic Bio-Fertilisers from Raw Nejayote}

The bio-fertilisers for edaphic application were prepared with raw nejayote (NC) at different percentages of dilution. The total number of bio-fertilisers prepared from raw nejayote is shown in Table 1 .

Table 1. Foliar and edaphic bio-fertilisers applied to native blue maize crops.

\begin{tabular}{ccccc}
\hline Number & Bio-fertilisers & Treatments & Dilution & Symbol \\
\hline 1 & Foliar & Control: Traditional bio-fertiliser & $5 \%$ & BT5 \\
2 & Foliar & Bio-fertiliser from raw nejayote & $5 \%$ & BNC5 \\
3 & Foliar & Bio-fertiliser from raw nejayote & $15 \%$ & BNC15 \\
4 & Foliar & Bio-fertiliser from raw nejayote & $30 \%$ & BNC30 \\
5 & Foliar & Bio-fertiliser from nejayote treated by & $5 \%$ & BNCQ5 \\
& a coagulation-flocculation process & & \\
7 & Foliar & Nejayote treated by a & $30 \%$ & NCQ30 \\
8 & Edaphic & coagulation-flocculation process & $0 \%$ & AP \\
9 & Edaphic & Control: Drinking water & $50 \%$ & NC50 \\
10 & Edaphic & Raw nejayote & $75 \%$ & NC75 \\
\hline
\end{tabular}




\subsection{Location and Climate Characteristics of the Experimental Plot}

The research was conducted in the municipality of Amozoc de Mota, Puebla, Mexico, located at $19^{\circ} 03^{\prime} 20.0$ north latitude and $98^{\circ} 03^{\prime} 06.0$ west longitude, with respect to the Greenwich meridian and at 2331 MASL. The climate in Amozoc de Mota is mild and subhumid, with summer rains $(100 \%)$. The temperature and precipitation ranges were $12^{\circ} \mathrm{C}-18^{\circ} \mathrm{C}$ and $900-1100 \mathrm{~mm}$, respectively. The soil in the region is composed of Leptosol (39\%), Luvisol (20\%), Arenosol (20\%), Phaeozem (1\%), and Durisol (1\%). Blue maize culture in this plot was conducted on a temporary basis.

\subsection{Soil Quality Assessment}

Before the date of sowing, soil samples were taken in a zigzag fashion across the lengthand breadth of the plot and at a depth of $0.30 \mathrm{~m}$. A composite sample was formed for physicochemical analysis. Four samples were collected 139 days after sowing (soil with drinking water and soil with raw nejayote at $50 \%, 75 \%$, and $100 \%$ ) for physicochemical analysis. The indicators of soil quality were as follows: $\mathrm{pH}$, electric conductivity, cation-exchange capacity, carbonates, bicarbonates, chlorides, sulphates, OM, total nitrogen, phosphorus, potassium, calcium, magnesium, sodium, iron, manganese, copper, zinc, texture, real density, apparent density, field capacity, permanent wilting point, usable moisture, irrigation lamina, and porosity. Variables were assessed on the basis of the Official Mexican Standard (Norma Oficial Mexicana) NOM-021SEMARNAT-2000.

\subsection{Experimental Design and Maize Cultivation}

A randomised block design was established with the application of 10 treatments and five replications, using native blue maize (Zea mays L.) as an indicator plant of the conic group 1a [18]. Each of the 50 experimental units consisted of $7.0 \mathrm{~m}^{2}$ with an inter-row distance of $0.70 \mathrm{~m}$. To avoid interference between the blocks, they were separated by a row where no sowing was performed. Five seeds were sown per bush, with a distance between bushes of $0.50 \mathrm{~m}$. When the plant reached $0.30 \mathrm{~m}$ of height, thinning was performed, and three plants were considered per bush. Each experimental unit was formed by 60 plants, with 18 plants per useful plot. During all the agricultural cycle, the maize cultivation was performed on a temporary basis, without irrigation of water, according to the prevalent technological circumstance of the region. Weed control was made by mechanical technique. The weeds were mowed each 15 days for remove the upper $0.12-0.15 \mathrm{~m}$ of taproot. The mowed weeds were taken away from the plot immediately. To avoid interferences with the proposed treatments (Table 1), any other fertilisers or input were not applied.

\subsection{Methodology for Applying Foliar and Edaphic Fertilisers to Maize Crops}

Fertiliser application from raw and treated nejayote included application on leaves (foliar) and soil (edaphic). In the case of foliar application, six treatments were applied 
with bio-fertilisers prepared at different dilutions, corresponding to treatments 1 - 6 of Table 1. In the case of edaphic application, four treatments were applied from dilutions of raw nejayote, corresponding to treatments $7-10$ of Table 1 , including the controls. A day before sowing, the seeds were moistened in the solutions of the respective treatments (Table 1). Then, the seeds were allowed to rest for $24 \mathrm{~h}$ before sowing. Cultivation was conducted from 1 May to 16 November 2015. Twenty-eight days after sowing, the first application of the foliar and edaphic treatments was performed. The following five applications were performed every 15 days. As the foliar area of the plant in the experimental units increased, so did the volume of foliar treatment, thus adding 45, 50, 55,60 , and $65 \mathrm{~mL}$ per bush at the first, second, third, fourth, and fifth applications, respectively. Soil applications of the treatments entailed flood irrigation. For this purpose, $3.00 \mathrm{~L}$ were utilised per bush. In each treatment, 30 plants were assessed to record plant height, stem diameter, and number of leaves, five times, every 21 days after 3 June. Maize cobs were harvested upon reaching physiological maturity. Two months thereafter, the grain moisture was measured with a moisture meter (TPM MD7822). Subsequently, the maize grain was weighed to calculate the yield.

\subsection{Statistical Analysis}

For the field foliar and edaphic treatments applied on native blue maize crops, the response variables plant height, stem diameter, number of leaves, and grain yield were assessed, with five replications, using Statgraphics Centurion XVI 16.1.02. All the variables were measured and analysed by a one-way ANOVA with Bartlett's test and a multifactor ANOVA with Tukey's range test, with $\alpha=0.05$ for the response variables of the foliar and edaphic field treatments.

\section{Results and Discussion}

\subsection{Characterization of Raw and Treated Nejayote}

The physicochemical characteristics of raw nejayote and nejayote treated through a coagulation-flocculation process are presented in Table 2. Raw nejayote has a dark yellow colour; it is highly alkaline and turbid, with a high organic load $\left(17,146 \mathrm{mgO}_{2} \cdot \mathrm{L}^{-1}\right)$ and electric conductivity. The content of nitrogen, phosphorus, potassium, calcium, magnesium, and iron is less than $1 \%$. The content of calcium in nejayote is relatively high and mainly stems from the calcium hydroxide used in the nixtamalisation process. The concentration of calcium ions in nejayote is relatively high if compared to the effluents of the dairy or food industry [19] [20]. For agricultural purposes, Ca represents an alternative for controlling the degree of soil suppressiveness against microorganisms (e.g., Aphanomyces euteiches) [21]. The percentage of OM in nejayote is considerably high and is attributed to pericarp waste that comes off the maize grain, whose composition, according to Watson and Ramstad (1987) [22], consists of ash (0.8\%), starch (7.3\%), sugars ( $0.3 \%)$, proteins (3.7\%), ether extract (1\%), and crude fibre $(86.7 \%)$. The OM present in nejayote can contribute in a mineralised form to agricultural crops, by releasing nutrients of its chemical and moistened composition, thus improving the soil 
Table 2. Physicochemical parameters of raw and treated nejayote.

\begin{tabular}{|c|c|c|}
\hline \multirow{2}{*}{ Parameter } & \multicolumn{2}{|c|}{ Nejayote } \\
\hline & Raw & Treated \\
\hline $\mathrm{pH}$ & 11.2 & 9.0 \\
\hline Colour $\left(\mathrm{m}^{-1}\right)$ & 50.40 & 15.40 \\
\hline Turbidity (NTU) & 1,072 & 143.0 \\
\hline Total Solids (\%) & 1.08 & 3.00 \\
\hline $\mathrm{COD}\left(\mathrm{mgO}_{2} \cdot \mathrm{L}^{-1}\right)$ & 17,146 & 14,058 \\
\hline Organic Matter (\%) & 61.48 & 11.90 \\
\hline Electric conductivity $\left(\mathrm{dS} \cdot \mathrm{m}^{-1}\right)$ & 3.95 & 2.36 \\
\hline Total Nitrogen (\%) & 0.08 & 0.06 \\
\hline Phosphorus (\%) & 0.015 & ND \\
\hline Potassium (\%) & 0.001 & 0.030 \\
\hline Calcium (\%) & 0.941 & 0.870 \\
\hline Magnesium (\%) & 0.174 & 0.400 \\
\hline Iron $(\%)$ & 0.0011 & ND \\
\hline
\end{tabular}

Abbreviations are as follows: NTU: Nephelometric Turbidity Unit; ND: Not detected.

structure and facilitating the availability of chelated minerals in plants. Nejayote treated by chemical coagulation with 7.5 to $11.5 \mathrm{~g} \cdot \mathrm{L}^{-1}$ Südflock ${ }^{\oplus} \mathrm{P}-63$ coagulant and $0.2 \times 10^{-3}$ g. $\mathrm{L}^{-1}$ flocculent (Sumex Biofloc ${ }^{\otimes} \mathrm{A}-01$ ) at $\mathrm{pH} 9.0$ modifies the physicochemical properties of raw nejayote, significantly reducing the colour and turbidity and partially reducing the organic load and ion presence in the solution. The most significant physicochemical characteristics of raw and treated nejayote are presented in Table 2. The reduction in the physicochemical parameters of the nejayote treated by coagulationflocculation generates a nejayote with a low concentration of organic and inorganic matter as a fertiliser in the agricultural processing of blue maize.

\subsection{Characterization of Foliar Bio-Fertilisers}

Table 3 presents the physicochemical parameters of the bio-fertilisers from raw and treated nejayote (BT, BCNQ, and BNC). Bio-fertilisers show $\mathrm{pH}$ values between 3.5 and 4.5 and an increased quantity of TS, turbidity, colour, OM content, and electric conductivity. The changes in the physicochemical characteristics of raw and treated nejayote are derived from the additional matter used in the preparation of bio-fertilisers (see Section 2.3). The increase in the electric conductivity of the bio-fertilisers observed indicates an increase in the content of salts or ions, as observed when comparing the data reported in Table 2 and Table 3. In the case of BNCQ, the electric conductivity has an additional ion contribution due to the bentonite used in the chemical coagulation treatment [23]. The total nitrogen and phosphorus content in bio-fertilisers is practically constant and in the same order of magnitude as the content from raw 
Table 3. Physicochemical parameters of the bio-fertilisers.

\begin{tabular}{lccc}
\hline & Parameter & \multicolumn{3}{c}{ Bio-fertilisers } \\
\cline { 2 - 4 } & BT & BNCQ & BNC \\
\hline $\mathrm{pH}$ & 3.7 & 4.0 & 4.1 \\
Total Solids (\%) & 38.47 & 8.18 & 9.73 \\
Colour (m ${ }^{-1}$ ) & 224.4 & 535.7 & 240.9 \\
Turbidity (NTU) & 2948 & 8232 & 3036 \\
Electric Conductivity (dS.m ${ }^{-1}$ ) & 12.49 & 15.41 & 15.47 \\
Organic Matter (\%) & 82.03 & 73.56 & 83.5 \\
Total Nitrogen (\%) & 0.09 & 0.12 & 0.01 \\
Phosphorus (\%) & 0.01 & 0.02 & 0.01 \\
Potassium (\%) & 0.12 & 0.10 & 0.13 \\
Calcium (\%) & 0.22 & 0.29 & 0.41 \\
Magnesium (\%) & 0.219 & 0.24 & 0.257 \\
Iron (\%) & 0.0059 & 0.0049 & 0.0058 \\
Manganese (\%) & 0.0013 & 0.0010 & 0.0007 \\
Zinc (\%) & 0.0011 & 0.0011 & 0.0010 \\
\hline Abbren & & \\
\hline
\end{tabular}

Abbreviation is as follows: NTU: Nephelometric Turbidity Unit.

nejayote. The calcium content in bio-fertilisers mainly comes from nejayote obtained from alkaline cooking (calcium hydroxide) during the nixtamalisation process. Both hydroxide and calcium carbonate function as alkalis and neutralise the acid products resulting from fermentation. In addition, calcium increases the $\mathrm{OM}$ mineralisation speed that contributes to the mobilisation of nutrients for the plants, especially of cellulose material, thus stimulating the bacterial activity of decomposition [24] [25] [26]. Together with this mobilisation of nutrients, the fulvic acids produced by fermentation form chelates with the metal ions $\mathrm{Mg}^{2+}, \mathrm{Ca}^{2+}, \mathrm{Fe}^{2+}$, and $\mathrm{Fe}^{3+}$, which facilitate the transport and regulate the bioavailability of these nutrients at the foliar level [27] [28]. Furthermore, it has been reported that in sites where acid rain is registered, the foliar application of calcium can reduce the adverse effects on crop cells caused by free radicals [29], thus promoting root growth and fruiting [30].

\subsection{Effect of Nejayote on the Cultivation of Maize Plants}

We assessed the effect of foliar and edaphic application of raw and treated nejayotebased fertilisers during maize plant development by a statistical analysis of the experimental data obtained by Tukey's range test $(\alpha=0.05)$ of diverse response variables at different stages of crop development: plant height $(\mathrm{cm})$, stem diameter $(\mathrm{mm})$, number of leaves, and grain yield $\left(\mathrm{t} \cdot \mathrm{ha}^{-1}\right)$. The different stages of crop development were classified as follows: 1) V5 (visible collar of the fifth leaf); 2) V8 (visible collar of the eighth leaf); 3) V9-VT (visible collar of the ninth leaf; last branch of the panicle visible); 4) 
VT-R0 (last branch of the panicle visible; male flowering) and 5) R1-R2 (visible stigmas in $50 \%$ of the plants; blister stage), as defined by Lafitte (1994) [31].

\subsubsection{Plant Height}

Table 4 presents the effect of the different treatments on the height of native blue maize plants. Plant height depends on genotype and on environmental conditions [32] [33]. Moreover, plant height is a response indicator, both for classification in terms of genotype difference and for the inputs applied to assess vegetal growth performance [34]. Given the morphological characteristics of the native blue maize studied herein, such a crop is identified as a la conic genotype [18]. According to data in Table 4, plant height increased throughout the different developmental stages. However, from the statistical analysis of results, it is evident that the effect of the treatments did not show any significant difference on plant height (Tukey $\mathrm{P} \leq 0.05)$ after foliar and edaphic fertilisation. Maximum plant height $(197.67 \mathrm{~cm})$ in the last measurement or R1-R2 stage was obtained with the edaphic application of the NC75 treatment. This height coincides with the findings of Sánchez et al. (2000) [18], who identified a minimum maize plant height of $142.7 \mathrm{~cm}$ and a maximum height of $294.3 \mathrm{~cm}$.

\subsubsection{Diameter of the Stem}

Table 5 presents the effect of the different treatments on the diameter of the stem of native blue maize plants. Analysed data revealed that at the V8 stage (26-06-2015), the effect of AP, BT5, and NCQ30 treatments on the stem diameter of maize plants was significantly different (Tukey $\mathrm{P} \leq 0.05$ ) in comparison with the rest of the treatments

Table 4. Effect of the different treatments on the height of native blue maize plants.

\begin{tabular}{lccccc}
\hline \multicolumn{5}{c}{ Plant height $(\mathrm{cm})$} \\
\hline Treatments & V5 & V8 & V9-VT & VT-R0 & R1-R2 \\
& $03 / 06 / 15$ & $26 / 06 / 15$ & $15 / 07 / 15$ & $05 / 08 / 15$ & $26 / 08 / 15$ \\
\hline AP & $25.12 \pm 2.28 \mathrm{a}^{1}$ & $61.68 \pm 4.70 \mathrm{a}$ & $105.66 \pm 9.00 \mathrm{a}$ & $162.62 \pm 6.50 \mathrm{a}$ & $176.00 \pm 8.96 \mathrm{a}$ \\
BT5 & $27.20 \pm 3.97 \mathrm{a}$ & $59.31 \pm 8.45 \mathrm{a}$ & $114.95 \pm 11.9 \mathrm{a}$ & $169.20 \pm 11.4 \mathrm{a}$ & $189.93 \pm 8.66 \mathrm{a}$ \\
NCQ30 & $25.91 \pm 2.10 \mathrm{a}$ & $60.38 \pm 3.16 \mathrm{a}$ & $102.58 \pm 8.22 \mathrm{a}$ & $158.14 \pm 9.19 \mathrm{a}$ & $174.47 \pm 10.3 \mathrm{a}$ \\
BNCQ5 & $26.15 \pm 2.68 \mathrm{a}$ & $56.90 \pm 5.08 \mathrm{a}$ & $107.77 \pm 12.8 \mathrm{a}$ & $165.50 \pm 17.6 \mathrm{a}$ & $185.50 \pm 14.1 \mathrm{a}$ \\
BNC5 & $27.47 \pm 2.11 \mathrm{a}$ & $57.87 \pm 4.20 \mathrm{a}$ & $112.03 \pm 11.1 \mathrm{a}$ & $160.57 \pm 11.5 \mathrm{a}$ & $179.27 \pm 10.9 \mathrm{a}$ \\
BNC15 & $26.42 \pm 1.64 \mathrm{a}$ & $60.40 \pm 5.32 \mathrm{a}$ & $112.00 \pm 10.0 \mathrm{a}$ & $168.12 \pm 15.1 \mathrm{a}$ & $178.50 \pm 11.8 \mathrm{a}$ \\
BNC30 & $26.37 \pm 2.49 \mathrm{a}$ & $60.85 \pm 4.70 \mathrm{a}$ & $108.05 \pm 5.76 \mathrm{a}$ & $172.17 \pm 5.11 \mathrm{a}$ & $190.27 \pm 8.07 \mathrm{a}$ \\
NC50 & $23.98 \pm 0.68 \mathrm{a}$ & $48.17 \pm 2.60 \mathrm{a}$ & $89.95 \pm 6.586 \mathrm{a}$ & $155.88 \pm 8.79 \mathrm{a}$ & $176.11 \pm 11.3 \mathrm{a}$ \\
NC75 & $24.13 \pm 2.55 \mathrm{a}$ & $54.95 \pm 5.00 \mathrm{a}$ & $103.93 \pm 11.4 \mathrm{a}$ & $182.23 \pm 9.41 \mathrm{a}$ & $197.67 \pm 10.6 \mathrm{a}$ \\
NC100 & $24.13 \pm 2.27 \mathrm{a}$ & $46.70 \pm 3.91 \mathrm{a}$ & $88.78 \pm 7.330 \mathrm{a}$ & $159.13 \pm 11.7 \mathrm{a}$ & $183.17 \pm 11.9 \mathrm{a}$ \\
\hline
\end{tabular}

${ }^{1}$ Mean \pm standard error. Equal letters indicate no significant difference (Tukey, $\mathrm{P} \leq 0.05$ ). Abbreviations are as follows: V5: visible collar of the fifth leaf; V8: visible collar of the eighth leaf; V9-VT: visible collar of the ninth leaf-last branch of the panicle visible; VT-R0: last branch of the panicle visible-male flowering; R1-R2: visible stigmas in $50 \%$ of the plants-blister stage. 
Table 5. Effect of the different treatments on the diameter of the stem of native blue maize plants.

\begin{tabular}{lccccc}
\hline \multicolumn{5}{c}{} & \multicolumn{4}{c}{ Diameter of the stem (mm) } \\
\hline Treatments & V5 & V8 & V9-VT & VT-R0 & R1-R2 \\
& $03 / 06 / 15$ & $26 / 06 / 15$ & $15 / 07 / 15$ & $05 / 08 / 15$ & $26 / 08 / 15$ \\
\hline AP & $8.4 \pm 0.8 \mathrm{a}^{1}$ & $17.9 \pm 0.80 \mathrm{~b}$ & $22.3 \pm 1.36 \mathrm{a}$ & $18.8 \pm 1.46 \mathrm{a}$ & $21.3 \pm 0.88 \mathrm{a}$ \\
BT5 & $9.1 \pm 0.8 \mathrm{a}$ & $18.8 \pm 0.73 \mathrm{~b}$ & $22.6 \pm 2.01 \mathrm{a}$ & $19.1 \pm 1.68 \mathrm{a}$ & $20.1 \pm 0.76 \mathrm{a}$ \\
NCQ30 & $8.5 \pm 0.7 \mathrm{a}$ & $18.3 \pm 0.67 \mathrm{~b}$ & $20.9 \pm 1.74 \mathrm{a}$ & $20.0 \pm 1.52 \mathrm{a}$ & $21.0 \pm 0.73 \mathrm{a}$ \\
BNCQ5 & $8.9 \pm 0.9 \mathrm{a}$ & $14.3 \pm 1.60 \mathrm{ab}$ & $22.3 \pm 1.26 \mathrm{a}$ & $18.5 \pm 1.22 \mathrm{a}$ & $20.2 \pm 0.60 \mathrm{a}$ \\
BNC5 & $8.6 \pm 0.7 \mathrm{a}$ & $14.8 \pm 1.32 \mathrm{ab}$ & $21.4 \pm 1.87 \mathrm{a}$ & $18.5 \pm 1.60 \mathrm{a}$ & $21.1 \pm 1.34 \mathrm{a}$ \\
BNC15 & $8.8 \pm 0.8 \mathrm{a}$ & $14.4 \pm 1.57 \mathrm{ab}$ & $21.9 \pm 0.68 \mathrm{a}$ & $18.8 \pm 1.03 \mathrm{a}$ & $20.9 \pm 0.80 \mathrm{a}$ \\
BNC30 & $8.7 \pm 0.7 \mathrm{a}$ & $14.9 \pm 1.85 \mathrm{ab}$ & $21.1 \pm 1.38 \mathrm{a}$ & $18.8 \pm 1.49 \mathrm{a}$ & $18.9 \pm 1.35 \mathrm{a}$ \\
NC50 & $7.6 \pm 0.3 \mathrm{a}$ & $14.8 \pm 0.36 \mathrm{ab}$ & $20.9 \pm 1.18 \mathrm{a}$ & $18.5 \pm 1.19 \mathrm{a}$ & $18.5 \pm 0.98 \mathrm{a}$ \\
NC75 & $8.1 \pm 0.6 \mathrm{a}$ & $16.5 \pm 1.72 \mathrm{ab}$ & $23.5 \pm 2.30 \mathrm{a}$ & $20.7 \pm 1.01 \mathrm{a}$ & $21.3 \pm 0.84 \mathrm{a}$ \\
NC100 & $8.3 \pm 0.8 \mathrm{a}$ & $11.4 \pm 0.65 \mathrm{a}$ & $20.6 \pm 1.67 \mathrm{a}$ & $18.0 \pm 2.03 \mathrm{a}$ & $20.5 \pm 0.85 \mathrm{a}$ \\
\hline
\end{tabular}

${ }^{1}$ Mean \pm standard error. Different letters (a y b) represent significant difference at $\mathrm{P} \leq 0.05$ confidence level by Tukey test between treatments for the same dependent variable. Abbreviations are as follows: V5: visible collar of the fifth leaf; V8: visible collar of the eighth leaf; V9-VT: visible collar of the ninth leaf-last branch of the panicle visible; VT-R0: last branch of the panicle visible-male flowering; R1-R2: visible stigmas in 50\% of the plants-blister stage.

(b). The maximum value for stem diameter $(18.8 \mathrm{~mm})$ was observed with the BT5 treatment (foliar bio-fertiliser at $5 \%$ ). A similar value $(18.3 \mathrm{~mm}$ ) was obtained with the NCQ30 treatment (nejayote treated by chemical coagulation), while the lowest stem diameter value $(11.4 \mathrm{~mm})$ was obtained with the NC100 treatment in comparison with the remaining treatments. It is possible that excess calcium may have been responsible for slowing the stem diameter growth at the V8 stage, given the increase in soil $\mathrm{pH}$ (Table 8) and the decrease in the availability of other nutrients [35].

According to Table 5, at subsequent stages of plant development, no statistically significant differences were observed in terms of the treatment's effect on the stem diameter. At the final stage (R1-R2), the maximum value of the stem diameter was $21.3 \mathrm{~mm}$ for the AP and NC75 treatments, whereas the minimum average value was $18.5 \mathrm{~mm}$ for the NC50 treatment. Moreover, it was noted that the diameter of the stem diminished considerably between the late vegetative phase and the beginning of female flowering (V9-VT to VT-R0). These results are consistent with the findings of Boomsma et al. (2009) [36]. Paul and Rowe (2011) [37] and Goodman and Ennos (1998) [38] indicate that such effects can be the result of the thigmomorphogenesis phenomenon, that is, a response to mechanical stimulation, in addition to the genetic characteristics of the conical race of native blue maize.

\subsubsection{Number of Leaves}

Table 6 presents the effect of the different treatments on the number of leaves of native blue maize. The results show significant differences between the treatments in terms of 
Table 6. Effect of the different treatments on the number of leaves of native blue maize plants.

\begin{tabular}{lccccc}
\hline \multicolumn{5}{c}{ Number of leaves } \\
\hline Treatments & V5 & V8 & V9-VT & VT-R0 & R1-R2 \\
& $03 / 06 / 15$ & $26 / 06 / 15$ & $15 / 07 / 15$ & $05 / 08 / 15$ & $26 / 08 / 15$ \\
AP & $5.27 \pm 0.28 \mathrm{a}^{1}$ & $7.97 \pm 0.27 \mathrm{~b}$ & $9.70 \pm 0.45 \mathrm{a}$ & $9.53 \pm 0.18 \mathrm{a}$ & $7.87 \pm 0.23 \mathrm{a}$ \\
BT5 & $5.27 \pm 0.15 \mathrm{a}$ & $8.58 \pm 0.31 \mathrm{~b}$ & $9.90 \pm 0.60 \mathrm{a}$ & $9.53 \pm 0.34 \mathrm{a}$ & $7.50 \pm 0.28 \mathrm{a}$ \\
NCQ30 & $5.13 \pm 0.28 \mathrm{a}$ & $7.73 \pm 0.17 \mathrm{~b}$ & $9.36 \pm 0.29 \mathrm{a}$ & $9.13 \pm 0.12 \mathrm{a}$ & $7.27 \pm 0.11 \mathrm{a}$ \\
BNCQ5 & $5.30 \pm 0.23 \mathrm{a}$ & $7.46 \pm 0.27 \mathrm{ab}$ & $9.30 \pm 0.72 \mathrm{a}$ & $9.30 \pm 0.25 \mathrm{a}$ & $7.63 \pm 0.08 \mathrm{a}$ \\
BNC5 & $5.43 \pm 0.23 \mathrm{a}$ & $7.88 \pm 0.28 \mathrm{~b}$ & $9.73 \pm 0.38 \mathrm{a}$ & $9.03 \pm 0.31 \mathrm{a}$ & $7.53 \pm 0.26 \mathrm{a}$ \\
BNC15 & $5.20 \pm 0.22 \mathrm{a}$ & $7.77 \pm 0.42 \mathrm{~b}$ & $9.37 \pm 0.32 \mathrm{a}$ & $9.43 \pm 0.29 \mathrm{a}$ & $7.30 \pm 0.14 \mathrm{a}$ \\
BNC30 & $4.77 \pm 0.19 \mathrm{a}$ & $7.87 \pm 0.45 \mathrm{~b}$ & $9.47 \pm 0.31 \mathrm{a}$ & $9.57 \pm 0.21 \mathrm{a}$ & $7.73 \pm 0.11 \mathrm{a}$ \\
NC50 & $5.14 \pm 0.21 \mathrm{a}$ & $7.10 \pm 0.12 \mathrm{ab}$ & $9.27 \pm 0.22 \mathrm{a}$ & $9.60 \pm 0.22 \mathrm{a}$ & $7.47 \pm 0.15 \mathrm{a}$ \\
NC75 & $5.07 \pm 0.29 \mathrm{a}$ & $7.13 \pm 0.47 \mathrm{ab}$ & $9.53 \pm 0.67 \mathrm{a}$ & $9.60 \pm 0.12 \mathrm{a}$ & $7.73 \pm 0.22 \mathrm{a}$ \\
NC100 & $5.33 \pm 0.27 \mathrm{a}$ & $6.13 \pm 0.22 \mathrm{a}$ & $9.27 \pm 0.38 \mathrm{a}$ & $9.50 \pm 0.44 \mathrm{a}$ & $7.60 \pm 0.36 \mathrm{a}$ \\
\hline
\end{tabular}

${ }^{1}$ Mean \pm standard error. Different letters (a y b) represent significant difference at $\mathrm{P} \leq 0.05$ confidence level by Tukey test between treatments for the same dependent variable. Abbreviations are as follows: V5: visible collar of the fifth leaf; V8: visible collar of the eighth leaf; V9-VT: visible collar of the ninth leaf-last branch of the panicle visible; VT-R0: last branch of the panicle visible-male flowering; R1-R2: visible stigmas in $50 \%$ of the plants-blister stage.

the number of leaves at the second measuring stage V8 (26-06-2015). At this stage, the number of leaves of maize plants revealed that the AP, BT5, NCQ30, BNC5, BNC15, and BNC30 treatments showed a statistically significant total difference (b) with respect to the highest values from $7.73 \pm 0.17$ to $8.58 \pm 0.31$, compared with the remaining treatments. The BNCQ5, NC50, and NC75 treatments resulted in significant statistical differences $(\mathrm{ab})$, with number of leaves ranging from $7.10 \pm 0.12$ to $7.46 \pm 0.27$ leaves. Lastly, the NC100 treatment also presented a significant statistical difference (a), with $6.13 \pm 0.22$ leaves.

At subsequent stages, the number of leaves did not reveal statistically significant differences in terms of treatment effects. Notably, the number of leaves increased from stage V5 to stages V9-VT but diminished from stage VT-R0 to stages R1-R2. Sánchez et al. (2000) [18] identified that for the conic group 1a, the minimum and maximum number of total leaves per plant was between 12.2 and 19.7. However, such findings do not agree with the number of leaves obtained in the fourth measurement at stage VT-R0 (Table 6). This difference stems from the fact that in this study, we only counted green leaves, thus excluding leaves that fell by stem expansion and ageing at the different stages of crop development [39].

\subsubsection{Grain Yield}

Table 7 shows the experimental data on weight $(\mathrm{g})$ and grain yield $\left(\mathrm{t} \cdot \mathrm{ha}^{-1}\right)$. Grain yield was determined when the seed had a moisture percentage of $12.5 \%$. In this sense, the grain yield of maize plants under different treatments or nutrient management presented the highest value $\left(0.639 \pm 0.121 \mathrm{t} \cdot \mathrm{ha}^{-1}\right)$ when subjected to the BNC5 treatment 
Table 7. Effect of different treatments on grain yield.

\begin{tabular}{lcc}
\hline \multicolumn{1}{c}{ Treatments } & Weight $(\mathrm{g})$ & Grain yield $\left(\mathrm{t} \cdot \mathrm{ha}^{-1}\right)$ \\
\hline AP & $329 \pm 74.8 \mathrm{ab}^{1}$ & $0.470 \pm 0.1070 \mathrm{ab}$ \\
BT5 & $411 \pm 49.1 \mathrm{ab}$ & $0.587 \pm 0.0702 \mathrm{ab}$ \\
NCQ30 & $214 \pm 8.32 \mathrm{ab}$ & $0.305 \pm 0.0119 \mathrm{ab}$ \\
BNCQ5 & $301 \pm 49.2 \mathrm{ab}$ & $0.430 \pm 0.0703 \mathrm{ab}$ \\
BNC5 & $447 \pm 84.8 \mathrm{~b}$ & $0.639 \pm 0.1210 \mathrm{~b}$ \\
BNC15 & $162 \pm 29.9 \mathrm{a}$ & $0.231 \pm 0.0428 \mathrm{a}$ \\
BNC30 & $252 \pm 45.2 \mathrm{ab}$ & $0.361 \pm 0.0648 \mathrm{ab}$ \\
NC50 & $343 \pm 29.6 \mathrm{ab}$ & $0.491 \pm 0.0422 \mathrm{ab}$ \\
NC75 & $276 \pm 67.1 \mathrm{ab}$ & $0.395 \pm 0.0959 \mathrm{ab}$ \\
NC100 & $371 \pm 36.9 \mathrm{ab}$ & $0.530 \pm 0.0527 \mathrm{ab}$ \\
\hline
\end{tabular}

${ }^{1}$ Mean \pm standard error. Different letters (a y b) represent significant difference at $\mathrm{P} \leq 0.05$ confidence level by Tukey test between treatments for the same dependent variable.

(raw nejayote-based bio-fertiliser at 5\%). Therefore, its effect established a statistically significant total difference (b) with respect to the remaining treatments. In addition, the BNC15 treatment generated the lowest value $\left(0.231 \pm 0.042 \mathrm{t} \cdot \mathrm{ha}^{-1}\right)$, compared with the rest of the treatments. The effect of the AP, BT5, NCQ30, BNCQ5, BNC30, NC50, NC75, and NC100 treatments did not show statistically significant differences (Tukey P $\leq 0.05)$. The interval of yield values obtained in this study $(0.231 \pm 0.043-0.639 \pm 0.121$ t.ha ${ }^{-1}$ ) was below the values reported by Nankar et al. (2016) [40]: $2.7-10.5$ t.ha ${ }^{-1}$. However, such yields were obtained in other conditions, other sites of study, and different varieties of blue maize.

In our study, some determining factors on low maize yield could be associated with the period between 15 July and 15 August, 2015 (stages V9-R1), when droughts were classified by the National Weather Service [41] as "abnormally dry", thus affecting the vegetative and reproductive development of native blue maize plants [40] [42] [43]. It has been reported that the yields per hectare of blue maize have been divergent [44] and that yield depends on the genetic variety cultivated [45], the environmental conditions [46], and the agronomic management of the crop [47].

\subsection{Physicochemical Analysis of the Soil}

Table 8 shows the physicochemical composition of soil before and after the application of the AP, NC50, NC75, and NC100 treatments. The soil texture was found to be loamy-sandy. This type of soil is easily eroded by wind [48], lacks cohesion [49], contains few exchangeable cations ( $\mathrm{Mg}, \mathrm{K}$, and $\mathrm{Ca}$ ), has low nutrient retention [50], and presents high permeability, low water retention capacity, and low specific heat [51]. However, such soils are easy to culture [52]. Raw nejayote (characterised in Table 2) contains a high percentage of OM (61.48\%) and calcium $(0.94 \%)$. Therefore, the edaphic fertilisation with the NC50, NC75, and NC100 treatments doubled the percentage of calcium 
Table 8. Physicochemical composition of soil before and after the application of the edaphic treatments.

\begin{tabular}{|c|c|c|c|c|c|}
\hline \multirow{2}{*}{ Parameter } & \multirow{2}{*}{$\begin{array}{l}\text { Before } \\
\text { application }\end{array}$} & \multicolumn{4}{|c|}{ After application } \\
\hline & & AP & NC50 & NC75 & NC100 \\
\hline $\mathrm{pH}$ & 7.45 & 6.20 & 6.09 & 5.85 & 6.26 \\
\hline Sand (\%) & 68 & 77 & 69 & 67 & 71 \\
\hline Clay (\%) & 16 & 14 & 20 & 18 & 10 \\
\hline Silt (\%) & 16 & 9 & 11 & 15 & 19 \\
\hline Texture & loamy-sandy & loamy-sandy & loamy-sandy & loamy-sandy & loamy-sandy \\
\hline Organic matter (\%) & 0.90 & 1.47 & 1.59 & 1.71 & 1.83 \\
\hline Real density $\left(\mathrm{g} \cdot \mathrm{cm}^{-3}\right)$ & 3.33 & 0.83 & 0.56 & 0.56 & 0.56 \\
\hline Apparent density $\left(\mathrm{g} \cdot \mathrm{cm}^{-3}\right)$ & 1.26 & 0.42 & 0.38 & 0.42 & 0.42 \\
\hline Field capacity (\%) & 18.91 & 12.54 & 18.74 & 15.19 & 11.76 \\
\hline Permanent wilting point (\%) & 10.28 & 6.28 & 10.18 & 7.95 & 5.80 \\
\hline Usable moisture (\%) & 8.62 & 6.26 & 8.56 & 7.24 & 5.97 \\
\hline Irrigation lamina $(\mathrm{cm})$ & 4.80 & 4.83 & 5.71 & 4.17 & 3.98 \\
\hline Porosity (\%) & 62.16 & 49.40 & 32.14 & 25.00 & 25.00 \\
\hline $\begin{array}{l}\text { Electric conductivity } \\
\left(\mathrm{dS} \cdot \mathrm{m}^{-1}\right)\end{array}$ & 1.42 & 0.71 & 0.84 & 0.45 & 0.04 \\
\hline $\begin{array}{l}\text { Cation Exchange Capacity } \\
\left(\mathrm{cmol} \cdot \mathrm{kg}^{-1}\right)\end{array}$ & 1.40 & 1.40 & 1.20 & 1.40 & 2.00 \\
\hline Total Nitrogen (\%) & 0.024 & 0.007 & 0.007 & 0.430 & 1.269 \\
\hline Phosphorus (\%) & 0.002 & ND & ND & ND & ND \\
\hline Potassium (\%) & 0.004 & ND & ND & ND & ND \\
\hline Calcium (\%) & 0.028 & 0.020 & 0.044 & 0.047 & 0.052 \\
\hline Iron (\%) & 0.0043 & 0.0019 & 0.0027 & 0.0030 & 0.0029 \\
\hline Manganese (\%) & 0.0001 & 0.0001 & 0.0003 & 0.0003 & 0.0003 \\
\hline Bicarbonates (\%) & 0.0491 & 0.0184 & 0.0061 & ND & 0.0061 \\
\hline Chlorides (\%) & ND & 0.0048 & 0.0064 & 0.0096 & 0.0032 \\
\hline Sulfates (\%) & 0.0257 & ND & ND & ND & ND \\
\hline
\end{tabular}

ND: Not detected.

ions and $\mathrm{OM}$ in the soil. The highest percentage of $\mathrm{OM}$ and calcium was registered in the NC100 treatment (raw nejayote at 100\%). When the calcium content increases in soil, generally, microbial growth is stimulated, thus positively affecting both nutrient availability and nitrogen fixation [26]. According to previous studies [10] [53], the addition of OM to soil increases the total pore volume, promotes aggregation, diminishes bulk density, and increases water retention capacity. Marsden (1989) [54] indicates that the calcium content increases the rate of decomposition of organic sediment matter, 
especially of cellulose material, as in the case of nejayote, while reducing the risk of disease propagation and neutralising the acids produced in the anaerobic decomposition of the OM. This effect favours the release of nutrients, increasing their availability for the crop. After the application of the edaphic treatments NC50, NC75, and NC100, the electric conductivity showed a considerable decrease, with values below the threshold indicated by Cramer (1994) [55]. According to Wang et al. (2014) [56], both calcium and the $\mathrm{OM}$ are effective for reducing soil salinity, which may explain the results obtained in terms of electric conductivity. Notably, an increase of the edaphic electric conductivity above $1.7 \mathrm{dS} \cdot \mathrm{m}^{-1}$ negatively affects total soil porosity, bulk density, and structural stability [57], thus preventing growth of maize plants [55]. Table 8 shows that the presence of elements such as nitrogen $(\mathrm{N})$, phosphorus $(\mathrm{P})$, and potassium $(\mathrm{K})$ was considerably low before the treatments. After the application of AP and NC50 treatments, the percentage of nitrogen diminished, while after the NC75 and NC100 treatments, the percentage of nitrogen increased significantly, especially in the NC100 treatment. This result can be attributed to nejayote. After the application of the treatments, $\mathrm{P}$ and $\mathrm{K}$ were not detected. Therefore, these elements are most likely to have been completely consumed by the crop. Prior to the application of the treatments, the soil had a slightly alkaline character $(\mathrm{pH}=7.45)$. However, after the treatments, the soil acquired a slightly acid character ( $\mathrm{pH}: 5.85$ - 6.26), which may have been caused by the acid character of the bio-fertiliser. Similar to $\mathrm{K}$ and $\mathrm{P}$, sulfates ions were not detected after the application of the treatments, whereas $\mathrm{Mg}^{2+}, \mathrm{Na}^{+}$, and $\mathrm{CO}_{3}^{2-}$ were not detected either before or after the applications. Most likely, their presence in nejayote was minimal, or they may have been completely consumed by the crop.

\section{Conclusion}

Raw nejayote was found to be of agricultural value, given its high content of organic and inorganic matter. Nejayote treated by a coagulation-flocculation process using the alkaline bentonite Südflock ${ }^{\circledR}$ P-63 and the anionic polyacrylamide Sumex Biofloc ${ }^{\circledR}$ A-01 at $\mathrm{pH}=9.0$ contributed to the significant reduction of the organic and inorganic content with respect to raw nejayote. In this manner, two nejayote states were established (raw nejayote and treated nejayote) with different physicochemical properties. Foliar and edaphic field treatments applied to native blue maize crops were statistically assessed through the following variable responses: plant height, stem diameter, number of leaves, and crop yield. The most significant effects of the foliar and edaphic application of raw and treated nejayote occurred at the early stage of plant development (the V8 stage, associated with a visible collar of the eighth leaf) and was mainly reflected by the stem diameter of the plant under NCQ30 treatment (nejayote treated by chemical coagulation at 30\%) and the number of plant leaves under BNC5 treatment (raw nejayotebased bio-fertiliser at 5\%). At the final stage of crop development, the highest yield was obtained with the BNC5 treatment (raw nejayote-based bio-fertiliser at 5\%, foliar application), which resulted in a statistically significant difference (b) in relation to the remaining foliar and edaphic treatments (Tukey $\mathrm{P} \leq 0.05$ ). This finding indicates a bet- 
ter efficiency of foliar absorption than edaphic absorption of nutrients. The proportion of raw or treated nejayote that is foliarly or edaphically applied is a determining factor for blue maize crops. Of the different treatments applied, only low concentrations of raw nejayote $(5 \%)$ and nejayote treated by chemical coagulation $(30 \%)$ yielded a favourable response. Therefore, raw nejayote or nejayote treated by chemical coagulation can be used in low concentrations as an agricultural input in the cultivation of maize.

\section{Acknowledgements}

The authors are grateful for the financial support provided by the project VIEP 2015. V. Téllez also thanks to CONACYT for scholarship granted.

\section{References}

[1] Cortés-Gómez, A., San Martín-Martínez, E., Martínez-Bustos, F. and Vázquez-Carrillo, G.M. (2005) Tortillas of Blue Maize (Zea mays L.) Prepared by a Fractionated Process of Nixtamalization: Analysis Using Response Surface Methodology. Journal of Food Engineering, 66, 273-281. http://dx.doi.org/10.1016/j.jfoodeng.2004.03.018

[2] Rosentrater, K.A. (2006) A Review of Corn Masa Processing Residues: Generation, Properties, and Potential Utilization. Waste Management, 26, 284-292.

http://dx.doi.org/10.1016/j.wasman.2005.03.010

[3] Salazar-Magallón, J.A., Hernández-Velázquez, V.M., Alvear-García, A., Arenas-Sosa, I. and Peña-Chora, G. (2015) Evaluation of Industrial by Products for the Production of Bacillus thuringiensis Strain GP139 and the Pathogenicity When Applied to Bemisia tabaci Nymphs. Bulletin of Insectology, 68, 103-109.

[4] Cifuentes, L. (2011) Nejayote Produced at Household Level by Mayan Women in Guatemala. Is It a Threat to Aquatic Ecosystems or a Resource for Food Security? Thesis Master Degree, Kristianstad University, Sweden.

[5] Njogu, R.N.E., Kariuki, D.K., Kamau, D.M. and Wachira, F.N. (2014) Effects of Foliar Fertilizer Application on Quality of Tea (Camellia sinensis) Grown in the Kenyan Highlands. American Journal of Plant Sciences, 5, 2707-2715. http://dx.doi.org/10.4236/ajps.2014.518286

[6] Singh, D.K., Pandey, A.K., Pandey, U.B. and Bhonde, S.R. (2002) Effect of Farmyard Manure Combined with Foliar Application of NPK Mixture and Micronutrients on Growth, Yield and Quality of Onion. Newsletter-National Horticultural Research and Development Foundation, 21-22, 1-7.

[7] Malakouti, M.J. (2008) Zinc Is a Neglected Element in the Life Cycle of Plants: A Review. Middle Eastern and Russian Journal of Plant Science and Biotechnology, 1, 1-12.

[8] Gómez-Galera, S., Rojas, E., Sudhakar, D., Zhu, C., Pelacho, A.M., Capell, T. and Christou, P. (2010) Critical Evaluation of Strategies for Mineral Fortification of Staple Food Crops. Transgenic Research, 19, 165-180. http://dx.doi.org/10.1007/s11248-009-9311-y

[9] Aghofack-Nguemezi, J. and Tatchago, V. (2010) Effects of Fertilizers Containing Calcium and/or Magnesium on the Growth, Development of Plants and the Quality of Tomato Fruits in the Western Highlands of Cameroon. International Journal of Agricultural Research, 5, 821-831. http://dx.doi.org/10.3923/ijar.2010.821.831

[10] Smith, G.H., Chaney, K., Murray, C. and Le, M.S. (2015) The Effect of Organo-Mineral Fertilizer Applications on the Yield of Winter Wheat, Spring Barley, Forage Maize and Grass Cut for Silage. Journal of Environmental Protection, 6, 103-109. 
http://dx.doi.org/10.4236/jep.2015.62012

[11] Zayas, T., Rómero, V., Salgado, L., Meraz, M. and Morales, U. (2007) Applicability of Coagulation/Flocculation and Electrochemical Processes to the Purification of Biologically Treated Vinasse Effluent. Separation and Purification Technology, 57, 270-276.

http://dx.doi.org/10.1016/j.seppur.2007.04.019

[12] Sher, F., Malik, A. and Liu, H. (2013) Industrial Polymer Effluent Treatment by Chemical Coagulation and Flocculation. Journal of Environmental Chemical Engineering, 1, 648-689. http://dx.doi.org/10.1016/j.jece.2013.07.003

[13] Suárez, K.A., Ponce, S.M., López, J.T., Cornejo, J.M., Oropeza, M.T. and López, E.A. (2016) Eco-Friendly Innovation for Nejayote Coagulation-Flocculation Process Using Chitosan: Evaluation through Zeta Potential Measurements. Chemical Engineering Journal, 284, 536542. http://dx.doi.org/10.1016/j.cej.2015.09.026

[14] Lee, L.S., Chang, E.U., Rhim, J.W., Ko, B.S. and Choi, S.W. (1997) Isolation and Identification of Anthocyanins from Purple Sweet Potatoes. Journal of Food Science and Nutrition, 2, 83-88.

[15] Salinas-Moreno, Y., Martínez-Bustos, F. and Soto-Hernández, M. (1999) Selection of Blue and Red Corn Grain Genotypes for Preparing Nixtamalized Corn Products and Other Derivatives. 10 th World Congress of Food Science \& Technology. Australian Institute of Food Science and Technology Incorporated, Sydney, 72.

[16] Stavric, B. (1994) Antimutagens and Anticarcinogens in Foods. Food and Chemical Toxicology, 32, 79-90. http://dx.doi.org/10.1016/0278-6915(84)90040-1

[17] Urias-Lugo, D.A., Heredia, J.B., Muy-Rangel, M.D., Valdez-Torres, J.B., Serna-Saldívar, S.O. and Gutiérrez-Uribe, J.A. (2015) Anthocyanins and Phenolic Acids of Hybrid and Native Blue Maize (Zea mays L.) Extracts and Their Antiproliferative Activity in Mammary (MCF7), Liver (HepG2), Colon (Caco2 and HT29) and Prostate (PC3) Cancer Cells. Plant Foods for Human Nutrition, 70, 193-199. http://dx.doi.org/10.1007/s11130-015-0479-4

[18] Sánchez, J.J., Goodman, M.M. and Stuber, C.W. (2000) Isozymatic and Morphological Diversity in the Races of Maize of Mexico. Economic Botany, 54, 43-59.

http://dx.doi.org/10.1007/BF02866599

[19] Hung, Y.T., Britz, T.J. and van Schalkwyk, C. (2006) Treatment of Dairy Processing Wastewaters. In: Wang, L.K., Hung, Y.T., Lo, H.H. and Yapijakis, C., Eds., Waste Treatment in the Food Processing Industry, CRC Press Taylor \& Francis, Boca Raton.

[20] Singh, S.N., Srivastava, G. and Bhatt, A. (2012) Physicochemical Determination of Pollutants in Wastewater in Dheradun. Current World Environment, 7, 133-138.

[21] Heyman, F., Lindahl, B., Persson, L., Wikström, M. and Stenlid, J. (2007) Calcium Concentrations of Soil Affect Suppressiveness against Aphanomyces Root Rot of Pea. Soil Biology \& Biochemistry, 39, 2222-2229. http://dx.doi.org/10.1016/j.soilbio.2007.03.022

[22] Watson, A.S. and Ramstad, E.D. (1987) Structure and Composition. In: White, P.J. and Johnson, L.A., Eds., Corn: Chemistry and Technology, the American Association of Cereal Chemists Inc., Saint Paul, 69-106.

[23] Loloei, M., Alidadi, H., Nekonam, G. and Kor, Y. (2014) Study of the Coagulation Process in Wastewater Treatment of Dairy Industries. International Journal of Environmental Health Engineering, 3, 12. http://dx.doi.org/10.4103/2277-9183.132684

[24] Vogel, H.C. and Todaro, C.L. (1997) Fermentation and Biochemical Engineering Handbook. Library of Congress Cataloging-in-Publication Data, 2nd Edition, Noyes Publications, Westwood.

[25] Delincé, G. (1992) The Ecology of the Fish Pond Ecosystem with Special Reference to Afri- 
ca. Springer, Berlin. http://dx.doi.org/10.1007/978-94-017-3292-5

[26] Gliński, J., Horabik, J., and Lipiec, J. (Eds.) (2011) Encyclopedia of Agrophysics. Institute of Agrophysics, Polish Academy of Sciences, Lubin.

[27] Vermeer, A.W.P. (1996) Interactions between Humic Acid and Hematite and Their Effects on Metal Ion Speciation. PhD Thesis, Wageningen University, Wageningen.

[28] Stevenson, F.J. (1994) Organic Forms of Soil Nitrogen. In: Stevenson, F.J., Ed., Humic Chemistry: Genesis, Composition, Reaction, 2nd Edition, Wiley, New York.

[29] Dolatabadian, A., Sanavy, S.A.M.M., Gholamhoseini, M., Joghan, A.K., Majdi, M. and Kashkooli, A.B. (2013) The Role of Calcium in Improving Photosynthesis and Related Physiological and Biochemical Attributes of Spring Wheat Subjected to Simulated Acid Rain. Physiology and Molecular Biology of Plants, 19, 189-198. http://dx.doi.org/10.1007/s12298-013-0165-7

[30] Chang, K.C.S., McGinn, J.M., Weinhert, E., Miller, S.A., Ikeda, D.M. and DuPonte, M.W. (2013) Natural Farming: Water-Soluble Calcium, Sustainable Agriculture. College of Tropical Agriculture and Human Resources University of Hawai'i at Mānoa, Honolulu, Hawai, SA-10, 1-3.

[31] Lafitte, H.R. (1994) Identifying Production Problems in Tropical Maize: A Field Guide. International Maize and Wheat Improvement Center (CIMMYT), Mexico.

[32] Zsubori, Z., Gyenes-Hegyi, Z., Illés, O., Pók, I., Rácz, F. and Szőke, C. (2002) Inheritance of Plant and Ear Height in Maize (Zea mays L.) Acta Agraria Debreceniensis, 8, 34-38.

[33] Sabiel, S.A.I., Abdelmula, A.A., Bashir, E.M.A., SunYingying, S.K., Yang, Y., Baloch, S.U. and Bashir, W. (2014) Genetic Variation of Plant Height and Stem Diameter Traits in Maize (Zea mays L.) under Drought Stress at Different Growth Stages. Journal of Natural Sciences Research, 4, 116-122.

[34] Ghaffari, A., Ali, A., Tahir, M., Waseem, M., Ayub, M., Iqbal, A. and Mohsin, A.U. (2011) Influence of Integrated Nutrients on Growth, Yield and Quality of Maize (Zea mays L.). American Journal of Plant Sciences, 2, 63-69. http://dx.doi.org/10.4236/ajps.2011.21009

[35] Malvi, U.R. (2011) Interaction of Micronutrients with Major Nutrients with Special Reference to Potassium. Karnataka Journal of Agricultural Sciences, 24, 106-109.

[36] Boomsma, R.C., Santini, B.J., Tollenaar, M. and Vyn, J.T. (2009) Maize Morphophysiological Responses to Intense Crowding and Low Nitrogen Availability: An Analysis and Review. Agronomy Journal, 101, 1426-1452. http://dx.doi.org/10.2134/agronj2009.0082

[37] Paul-Victor, C. and Rowe, N.P. (2011) Effect of Mechanical Perturbation on the Biomechanics, Primary Growth and Secondary Tissue Development of Inflorescence Stems of Arabidopsis thaliana. Annals of Botany, 107, 209-218.

http://dx.doi.org/10.1093/aob/mcq227

[38] Goodman, A.M. and Ennos, A.R. (1998) Responses of the Root Systems of Sunflower and Maize to Unidirectional Stem Flexure. Annals of Botany, 82, 347-357. http://dx.doi.org/10.1006/anbo.1998.0693

[39] O'Keeffe, K. and NSW [New South Wales] (2009) Maize Growth \& Development. Department of Primary Industries. NSW Department of Primary Industries (Orange, NSW), United Kingdom.

[40] Nankar, A., Grant, L., Scott, P. and Pratt, R.C. (2016) Agronomic and Kernel Compositional Traits of Blue Maize Landraces from the Southwestern United States. Crop Science, 56, 2663-2674. http://dx.doi.org/10.2135/cropsci2015.12.0773

[41] SMN (National Meteorological Service) (2015) Drought Monitor in Mexico. http://smn.cna.gob.mx/index-.php?option=com_content\&view=article\&id=20\&Itemid=74 
[42] Saini, H.S. and Westgate, M.E. (2000) Reproductive Development in Grain Crops during Drought. Advances in Agronomy, 68, 59-96. http://dx.doi.org/10.1016/S0065-2113(08)60843-3

[43] Aguilar, M., Borjas, F. and Espinosa, M. (2007) Agronomic Response of Maize to Limited Levels of Water under Furrow Irrigation in Southern Spain. Spanish Journal of Agricultural Research, 5, 587-592. http://dx.doi.org/10.5424/sjar/2007054-280

[44] Betrán, F.J., Bockholt, A.J. and Rooney, L. (2001) Blue Corn. In: Hallauer, A.R., Ed., Specialty Corns, CRC Press, Boca Raton, Chapter 10.

[45] Wang, T.Y., Ma, X.L., Li, Y., Bai, D.P., Liu, C., Liu, Z.Z., Tan, X.J., Shi, Y.S., Song, Y.C., Carlone, M., Bubeck, D., Bhardwaj, H., Jones, E., Wright, K. and Smith, S. (2011) Changes in Yield and Yield Components of Single-Cross Maize Hybrids Released in China between 1964 and 2001. Crop Science, 51, 512-525. http://dx.doi.org/10.2135/cropsci2010.06.0383

[46] Liu, Y., Wang, E.L., Yang, X.G. and Wang, J. (2010) Contributions of Climatic and Crop Varietal Changes to Crop Production in the North China Plain since 1980s. Global Change Biology, 16, 2287-2299. http://dx.doi.org/10.1111/j.1365-2486.2009.02077.x

[47] Duvick, D.N. (1997) What Is Yield? In: Edmeades, G.O., Bänziger, M., Mickelson, H.R. and Peña-Valdivia, C.B., Eds., Developing Drought and Low N-Tolerant Maize, CIMMYT, Mexico, 332-335.

[48] Ademosun, O.C. (1990) The Design and Operation of a Soil Tillage Dynamics Equipment. The Nigerian Engineer, 25, 51-57.

[49] Guinness, P. and Walpole, B. (2016) Environmental Systems and Societies for the IB Diploma Coursebook. 2nd Edition, Cambridge University Press, Cambridge.

[50] Zhao, Y.G., Zhang, G.L., Wen-Jun, Z. and Gong, Z.T. (2005) Soil Characteristics and Crop Suitability of Sandy Soils in Hainan, China. Management of Tropical Sandy Soils for Sustainable Agriculture: A Holistic Approach for Sustainable Development of Problem Soils in the Tropics, Bangkok, 27 November-2 December 2005, 49-66.

[51] Van Wambeke, A. (1992) Soils of the Tropics-Properties and Appraisal. McGraw Hill Inc., New York.

[52] Mojid, M.A., Mustafa, S.M.T. and Wyseure, G.C.L. (2009) Growth, Yield and Water Use Efficiency of Wheat in Silt Loam-Amended Loamy Sand. Journal of the Bangladesh Agricultural University, 7, 403-410.

[53] FAO (Food and Agriculture Organization of the United Nations) (2005) The Importance of Soil Organic Matter. Key to Drought-Resistant Soil and Sustained Food and Production. FAO Soils Bulletin 80, Rome.

[54] Marsden, M.W. (1989) Lake Restoration by Reducing External Phosphorus Loading: The Influence of Sediment Phosphorus Release. Freshwater Biology Journal, 21, 139-162. http://dx.doi.org/10.1111/j.1365-2427.1989.tb01355.x

[55] Cramer, G.R. (1994) Response of Maize (Zea mays L.) to Salinity. In: Pessarakli, M., Ed., Handbook of Plant and Soil Stresses, Marcel Dekker, New York, 449-459.

[56] Wang, L., Sun, X., Li, S., Zhang, T., Zhang, W. and Zhai, P. (2014) Application of Organic Amendments to a Coastal Saline Soil in North China: Effects on Soil Physical and Chemical Properties and Tree Growth. PLOS ONE, 9, e89185. http://dx.doi.org/10.1371/journal.pone.0089185

[57] Tejada, M. and González, J.L. (2005) Beet Vinasse Applied to Wheat under Dryland Conditions Affects Soil Properties and Yield. European Journal of Agronomy, 23, 336-347. http://dx.doi.org/10.1016/j.eja.2005.02.005 
Submit or recommend next manuscript to SCIRP and we will provide best service for you:

Accepting pre-submission inquiries through Email, Facebook, LinkedIn, Twitter, etc. A wide selection of journals (inclusive of 9 subjects, more than 200 journals)

Providing 24-hour high-quality service

User-friendly online submission system

Fair and swift peer-review system

Efficient typesetting and proofreading procedure

Display of the result of downloads and visits, as well as the number of cited articles

Maximum dissemination of your research work

Submit your manuscript at: http://papersubmission.scirp.org/

Or contact ajps@scirp.org 